\title{
Excise Duty Gap on Cigarettes
}

\author{
Maris Juruss ${ }^{1}$, Baiba Smite-Roke², Liga Gasune ${ }^{3}$ \\ ${ }^{1,3}$ Riga Technical University \\ Kalku st. 1, LV-1658, Riga, Latvia \\ E-mail.maris,juruss@rtu.lv,liga.gasune@inbox.lv \\ ${ }^{2}$ State Revenue Service \\ Talejas st. 1, LV-1978 Riga, Latvia \\ E-mail.Baiba.Smite-Roke@vid.gov.lv \\ cross $^{\text {ref }}$ http://dx.doi.org/10.5755/j01.ee.29.4.20335
}

The largest part of indirect taxes is excise duty and there are significant loses in tax revenues from illegal trade of such goods as cigarettes due to the fact they are taxed with a very high excise duty burden and therefore there is a very high level of smuggling and illegal trade in all European Union member states. The expansion of the illegal market to the eastern borders of the European Union has been driven by an increase in excise duties on cigarettes, with subsequent price rises. Some of the previous studies were trying to find the best methodology for measuring the tax gap but there were indicate some difficulties and no common approach to estimate excise duty gap on cigarettes in the European Union. The authors are used a top-down methodology to designed a methodology how to estimate the excise duty gap on cigarettes. The objective of this article is to present an overview study of tax gap estimations, calculate the excise duty gap on cigarettes in Latvia, discuss the best practice how to limit the tax gap and protect the legal market, as well as develop recommendations for improvement of tax administration. The problem of protecting the legal market by stoppage and reduction of cigarettes smuggling is on the agenda of the European Union.

Keywords: Excise Duty; Revenues; Tax Gap; Illicit Market; Customs Authorities; Top-Down Methodology.

\section{Introduction}

There have been a number of studies of the value added tax (VAT) gap in the European Union (EU) (Reckon, 2009; Barbone, Bonch-Osmolovskiy \& Poniatowski, 2015). However, more significant loses are from the illegal trade with such goods as cigarettes, as they are taxed with a very high excise duty burden and therefore there is very high smuggling and illegal trade in all EU member states which impacts both excise duty and VAT gap.

The expansion of the illegal market to the eastern borders of the EU has been driven by an increase in excise duties on cigarettes, with subsequent price rises. With a desire to save, the consumers search for cheaper ways to get the desired cigarettes, therefore consumers buy cigarettes in the illicit market.

The smuggling is caused by geographical location to neighboring countries where the prices of cigarettes are substantially lower than in the EU. On the agenda of the EU institutions there is a legitimate protection of the cigarette market by reducing smuggling. Smuggling interacts with different types of processes, so tax and customs experts are looking for new and more effective methods to curb the flow of illegal cigarettes. The legal protection of the tobacco market, the limitation of illegal trade, the fight against smuggling, the abolition of illicit manufacturing and the cessation of counterfeit products are the priorities of the tax administration for the coming years.

The total consumption of illegal cigarettes in the EU is about 56.6 billion cigarettes (KPMG, 2015). For example, in Latvia in 2014 the percentage of illicit cigarette market was 29.3 per cent of the total cigarette consumption, making Latvia a country with the highest proportion of illegal cigarette consumption in the EU (KPMG, 2015). The necessity to increase excise duty was implemented with changes in excise tax legislation, increasing the price of cigarettes on the legal market. As of 1 July 2018, the excise duty on cigarettes in Latvia should be minimum EUR 100 per 1000 cigarettes.

Cigarette smuggling and other forms of illicit trade in tobacco products cause an estimated EUR 10 billion loss to the EU and national budgets every year. It is necessary to estimate the excise duty gap on cigarettes and set an action plan how to reduce it.

The aim of this research is to estimate excise duty gap on cigarettes used top-down methodology and developing recommendations for improving tax administration. The objectives are: overview study of tax gap estimations, by the designed methodology, as a case study, calculate the excise duty gap on cigarettes in Latvia, study the best practice how to limit the tax gap and protect legal market, as well as develop recommendations for improvement of tax administration.

Qualitative analysis of scientific researches and regulations and quantitative data analysis about tax revenues was used as a research methodology.

\section{Literature Review}

Most of the developed and developing countries the taxes are a major source of revenue. Therefore, tax evasion 
is a worldwide problem. For example, the smuggling activities involving cigarettes have caused a great loss to tax revenues in many countries. Various factors can negative or decreasing affect the amount of excise duty gathering, for example, the tax rate, the fairness of taxes, the penalty rate, the influence of peers and tax agents (Sinnasamy, Bidin \& Ismail, 2015).

The tax evasion is a major cause of inefficiency in the market, reducing the ability of the state to raise funds, which in turn has an impact on economic and social policy delivery. (Kasnauskiene \& Krimisieraite, 2015).

Mazur and Plumley have argued the tax gap is defined as the difference between the amount of tax imposed by the tax code and the amount that is reported and paid with timely filed returns (Mazur \& Plumley, 2007).

A common approach is used to calculate the VAT difference in the EU. It is calculated as the difference between the theoretical VAT liability and VAT collection in any country and any year (in absolute or in percentage terms). The "top-down" methodology developed by Reckon (Reckon, 2009) is used to calculate the theoretical VAT liabilities, which is adjusted if necessary. The methodology used has been supplemented, as reports from several EU Member States authorities have made it possible to improve the accuracy of key parameters (Barbone, BonchOsmolovskiy \& Poniatowski, 2015).

The VAT difference is not always a VAT fraud, for example, the VAT difference may include VAT that has not been paid as a result of legitimate tax avoidance measures or have been affected by the accuracy and completeness of the data, as the VAT difference is estimated on the basis of national accounts data. It does not take into account taxable activities, which are outside of government accounts. Nor it does include data adjusting the assumptions for VAT differences in cases where VAT has not been collected due to insolvency of companies that resulting from regular business activities. Since precise data can not be obtained, it can not, however, be considered as part of the VAT which is not transferred in relation to VAT fraud. (Reckon, 2009). This should be taken in consideration in defining also excise duty gap.

The largest part of indirect taxes is excise tax and the main problem in the national and international area has become tax fraud. There is a significant difference between declared excise duty and actual excise duty values in any country, in which excise duty is in place (Miskam, Noor, Omar \& Aziz, 2013).

Economic stability and public policy can be significantly influenced by the existence of a shadow economy in the country. The choices made and the measures taken may be different as they are not regulated as they are in the official field. It can affect growth prospects as it can endanger social infrastructure. They suffer public finances as the tax base decreases, thus reducing the government's ability to generate revenue. If there is no possibility to obtain official statistics of sufficient quality, policy makers' assessments and recommendations may lead to even greater inaccuracy. Therefore, the size of the informal sector is a challenge that needs to be addressed and an important task is to understand what factors can affect it (Blackburn, Bose \& Capasso, 2012).
The illegal sales constituted 11 per cent of all cigarettes sold in 2011 and $10.4 \%$ of the cigarettes were sold illegally in the EU, respectively, which indicates that in more than 5 years no efficient enough methods have been found to reduce this amount (Cooper \& Vitt, 2011).

It should be mentioned, that mainly illicit cigarettes are purchased by lower income level earners as high prices have more impact to this group of consumers. Studies shows, that lower income households tend to be less compliant than higher income households (Alm \& Borders, 2014).

At least, the complexity of the tax system can be a significant determinant of non-compliance (MorganThomas, 2013).

There is no common approach to estimate excise duty gap on cigarettes in the EU. However, the excise duty gap is regularly measured in many national tax and customs administrations, for example, in the United Kingdom (HM Revenue \& Customs, 2013).

The studies show the difficulties to find the best methodology for measuring the tax gap. In order to choose the appropriate methods, the exact subject of the research must be determined, i.e. prohibited, illegal or distorting activity or tax evasion. Similarly, the application of this method should take into account historical and actual data, as the rapidly changing situation and the various factors may affect the results. (Davida \& Semerada, 2014).

\section{Methodology}

At this article for the design of excise duty gap on cigarettes are used a top-down methodology. Top-down methodologies based on a macro perspective usually employ economy-wide aggregates. Top-down methodologies are based on the assumption that the data source used to calculate tax differences covers the entire tax base. This methodology uses uniform estimates based on data that is independent of the tax administration. (Rubin, 2011) If the tax administration's operational information is planned and potentially contaminated with management issues, this can be particularly beneficial. (Keen, 2013) In general, it is similar to the methodology used by tax and customs authorities in the UK (HM Revenue and Customs 2013), however, it has some specific differences. The methodology includes the following steps (see Table 1).

The results should be corrected by the following factors: legally imported duty not paid cigarettes within private limits, legally purchased cigarettes, but exported by private consumers and other factors as error in calculations. However, due to the limited availability of such information, for correction are used assumption margin of 5 per cent.

The methodology can be used to measure the excise duty gap on cigarettes and therefore to set it as key performance indicator for further activities to reduce illicit trade and duty non-compliance. 
Steps for Estimation of Excise Duty Gap on Cigarettes

\begin{tabular}{|c|c|c|}
\hline No & Step & Action \\
\hline 1 & Total consumption & $\begin{array}{l}\text { The Total consumption }\left(C_{T}\right) \text { by combining the following information: } \\
\text { - estimates of prevalence (proportion of the population that smokes cigarettes) from the Health Survey; } \\
\text { - estimates of cigarette consumption per smoker from the Health Survey; } \\
\text { - data about the adult population; and } \\
\text { - a correction factor covering under-reporting. }\end{array}$ \\
\hline 2 & Legitimate consumption & Data about the Legitimate consumption $\left(C_{L}\right)$ \\
\hline 3 & Illicit consumption & $\begin{array}{l}\text { Calculation of the Illicit consumption }\left(C_{I}\right) \text { by formula 1. Subtraction from the Total consumption }\left(C_{T}\right) \text { the } \\
\text { Legitimate consumption }\left(C_{L}\right) \text {. } \\
\qquad C_{I}=C_{T}-C_{L}\end{array}$ \\
\hline 4 & Revenue losses & $\begin{array}{l}\text { Calculation the Revenue losses }(L) \text { by formula } 2 \text {. Multiplied the Illicit consumption }\left(C_{I}\right) \text { by the Excise duty rate } \\
\qquad L=C_{I} \times T\end{array}$ \\
\hline 5 & Excise duty revenues & Obtained data about the Excise duty revenues $(R)$ \\
\hline 6 & Excise duty gap & $\begin{array}{l}\text { Estimated the Excise duty gap }(G) \text { by formula } 3 \text {. Excise duty gap is expressed as per cent of the total potential } \\
\text { revenues or from sum of Revenue losses }(L) \text { and the Excise duty revenues }(R) . \\
\qquad G=L /(L+R)\end{array}$ \\
\hline
\end{tabular}

Author's construction based on UK methodology

\section{Results}

For a case study to estimate the excise duty gap on cigarettes in Latvia are used previously described methodology. As the result in 2016 estimated the excise duty gap on cigarettes was 35 per cent.

For case study for estimation of the total amount of consumed cigarettes are used the Survey of Health Behavior among Latvian Adult Population in Latvia (SKPC, 2015). In this survey the combined sampling method was used - a method of stratified random sampling and quota. The sample was stratified by sex, age, place of residence, city, municipality, region and nationality. Data about the adult population was obtained from Central Statistical Bureau (CSP, 2017).

According to the survey the smoking prevalence is 53.6 per cent among men, 22.3 per cent among women and total 36.3 per cent among all individuals over 15-year-old (see Table 2). Smokers amount are estimate by smoking prevalence on 2014 (last available findings) and adult population on 2016.

Estimated Smokers in Latvia (2016)

Table 2

\begin{tabular}{|c|c|c|c|}
\hline & Men & Women & Total \\
\hline Individuals over 15 years & 749926 & 918771 & 1668697 \\
\hline Smoking prevalence, $\%$ & 53.6 & 22.3 & 36.3 \\
\hline Smokers, total & 401960 & 204886 & 605737 \\
\hline
\end{tabular}

Source: Created by the authors by the data from CSP (2016) and SKPC (2014)

Used data from the survey about respondents smoking behavior the estimation of total smoke 8081944 cigarettes per day - men in total smoke 5915994 cigarettes each day or 2.159 billion units per year, women smoke 2165950 cigarettes per day or 0.791 billion units per year.
The total consumption of cigarettes (CT) in Latvia is estimated at 2.950 billion units per year.

For the case study about Latvia are used the information provided by the State Revenue Service (SRS, 2016). In 2016 the legitimate consumption (CL) in Latvia was only 1.924 billion cigarettes (see Table 3 ).

Table 3

Results of Excise Duty Gap on Cigarettes

\begin{tabular}{|l|l|l|}
\hline \multicolumn{1}{|c|}{ No } & \multicolumn{1}{c|}{ Rep } & \multicolumn{1}{c|}{ Results } \\
\hline 1 & Total consumption & 2.950 billion cigarettes per year \\
\hline 2 & Legitimate consumption & 1.924 billion cigarettes per year \\
\hline 3 & Illicit consumption & 1.026 billion cigarettes \\
\hline 4 & Revenue losses & 98 million EUR \\
\hline 5 & Excise duty revenues & 183.8 million EUR \\
\hline 6 & Excise duty gap & 35 per cent \\
\hline
\end{tabular}

Autor's construction based on State Revenue Service (SRS, 2016), Central Statistical Bureau (CSP, 2017) data

\section{Discussion}

In according to used methodology calculated the excise duty gap on cigarettes, it is estimate to 35 per cent in 2016 , but used similar method upon information of 2014 excise duty gap on cigarettes was 37 per cent. By the year excise duty gap on cigarettes are increase and that shows when the illicit cigarette market are grow.

In other countries are similar problem like Latvia, example, in compliance with The Tobacco Manifacture's 
association in the United Kingdom information, then in United Kingdom 2016 survey found that $71 \%$ of smokers had purchased non-UK duty paid products and $20 \%$ are aware of illicit tobacco being sold in their area. (The Tobacco Manufacture's association in the United Kingdom, 2017)

Realized this problem the tax authority need to developing recommendations for improving tax administration.

Experts have studied the factors influencing the illicit cigarette market and have identified several elements essential in the fight against smuggling: understand and monitor the size and nature of the problem, evaluate the main facilitators, balance tax policy and effective tax collection, ensure that regulations work, the penalties are adequate, develop an enforcement strategy, provide adequate financial resources for law enforcement capabilities, address demand by building and strengthening partnerships between national and international agencies, educating and informing the public, cooperating with legitimate players of the industry (International Tax and Investment Center, 2003).

Payment of taxes is the responsibility of citizens who are afraid of possible sanctions that they will suffer if they accept the indifferent attitude to tax payment. The fight against tax evasion is, of course, the first to do with the phenomenon of tax evasion. Avoiding tax can lead to a true escapist gene, passed on from generation to generation, may persist for a long time, with significant negative effects on the economy for many years to come. The increase of penalties must be sufficient enough to eliminate criminal behavior (Lazar, 2013).

Changing taxpayers attitudes is another step towards stopping tax evasion, along with the exponential change of attitude of the tax administration towards taxpayers by developing a partnership between them (Lazar, 2013).

Typically, the tax gap need to be attacked at once in several areas and with a number of sustainable strategies. These strategies could include simplifying tax code, providing taxpayers with quality of services and improving tax compliance through tax withholding and reporting (Tax Gap, 2005).

Sometimes strategies for reducing the tax gap are related to the introduction of tax laws and the improvement of taxpayer services, but there is no clear emphasis on quantifying long-term goals or results. The definition of clear objectives and the assessment of their achievements are in line with the results-oriented management principles. Such a strategic approach to the tax administration will provide a solid basis for reducing the tax gap (Tax Gap, 2005).

As a matter of high priority, the European Commission has imposed a ban on the smuggling of goods, in particular cigarettes from neighboring countries, such as Moldova, Ukraine, Belarus and Russia. The Action Plans developed include a number of actions to implement this task, including, for example, to help detect smuggling, provides installation of the latest generation of technical equipment (scanners, automated identification tools and night vision equipment) at border checkpoints. (TAXUD, 2013).

One of the possible solutions to control illegal market is the development and implementation of Track \& Trace system. (TAXUD, 2014). There has been a discussion about it in Latvia as well (Cabinet of Ministers, 2013). There are two main principles for improving the situation by this system. Firstly, it should be possible to track the distribution of tobacco products and control authorities in order to be able to request and receive relevant information. Secondly, the system provides for the control authorities of the Member States to identify the origin of tobacco products with the introduction of safe, specific, unique and indelible markings, which allows them to track their movements, and to control the flow of tobacco products and their legal status. The introduction of the Track \& Trace system is a resourceintensive project and is currently optional for the EU Member States. For example, Lithuania has already launched a pilot project. Individual countries also support Track \& Trace system such as Austria, Ireland and the United Kingdom.

Despite the increase in the illegal market and the increase in excise duties, the intended development of the technical resources of the customs authorities gives rise to greater certainty that customs officers will be provided with adequate resources to fight smuggling, thus ensuring the protection of the entire European Union market.

In order to act more proactively and reduce the risks associated with the illicit market, increasing the appropriate collection of taxes, tax and customs authorities should more actively consider new ways of dealing. The taxation and customs should consider developing and using more dog handler services. In order to improve physical control, customs officers should develop training programs, for example, using seized vehicles and experience with detected violations in the learning process.

It is also important to increase the motivation of employees and to evaluate the work of all the control authorities by increasing their salaries, allowances for violations found and introducing other incentives.

\section{Conclusion}

The methodology how to estimate excise duty gap on cigarettes on case study, who based on top-down methodology, shows that in 2016 there was a significant excise duty gap on cigarettes in Latvia: 35 per cent comparing with estimate excise duty gap on cigarettes in 2014 it reduced by 2 percentage points. Reduce of excise duty gap explained with improvement of tax administration and fight of illegal trade. The methodology can be used to measure excise duty gap on cigarettes and therefore to set it as key performance indicator for further activities to reduce illicit trade and duty non-compliance.

The tax and customs authorities should be more active in considering the new ways of how to reduce the risks associated with illegal market and to charge appropriate taxes, for example, develop dog handler service, set trainings for customs officials in improving physical controls. Moreover, the common action plan should be developed at European Union level, and Track\&Trace system shall be introduced in the control of trade of cigarettes.

\section{References}

Alm, J., \& Borders, K. (2014). Estimating the "Tax Gap" at the State Level: The Case of Georgia's Personal Income Tax. Public Budgeting \& Finance, 34, 61-79. https://doi.org/10.1111/pbaf.12050 
Luca, B., Bonch-Osmolovskiy, M., \& Poniatowski, G. (2015). Study to quantify and analyse the VAT Gap in the EU member states. CASE Network Reports no. 124, 1-61.

Blackburn, K., Bose, N., \& Capasso, S. (2012). Tax evasion, the underground economy and financial development. Journal of Economic Behavior and Organization, 83, 243-253. https://doi.org/10.1016/j.jebo.2012.05.019

Cabinet of Ministers. (2013). Report on implementation of Track\&Trace excise goods (cigarettes) supervision system into Latvia. The Cabinet of Ministers of the Republic of Latvia.

Cooper, A., \& Vitt, D. (2011). The linkage between tax burden and illicit trade of excisable products: the example of tobacco. World Customs Journal. International Network of Customs University. Available from internet: cooperation/combating_tax_fraud/reckon_report_sep2009.pdf

CSP. (2017). General statistic. Central Statistical Bureau in Latvia.

Davida, P., \& Semerada, P. (2014). Possibilities of measuring tax evasion related to fuel sale. Enterprise and the Competitive Environment 2014 conference, ECE 2014, 6-7 March 2014, Brno, Czech Republic. Procedia Economics and Finance 12, 121-129. https://doi.org/10.1016/S2212-5671(14)00327-X

HM Revenue and Customs. (2013). Methodological annex for measuring tax gaps 2013. UK.

International Tax and Investment Center. (2013). The Illicit Trade in Tobacco Products and How to Tackle It. Second Edition.

Kasnauskiene, G., \& Krimisieraite, J. (2015). Using Mimic Models to Examine Determinants of vat gap in Lithuania. Organizations \& Markets in Emerging Economies, 6(1), 107-126.

Keen, M. (2013). The Anatomy of the VAT, IMF working paper, WP/13/111, Retrieved from https://www.imf.org/external/pubs/ft/wp/2013/wp13111.pdf

KPMG (2015). Project SUN. A study of the illicit cigarette market in the European Union.

Lazar, R. (2013). Tax Evasion between Legality and Criminal Offense. Procedia - Social and Behavioral Sciences, 92 (Logos Universality Mentality Education Novelty (LUMEN 2013), Iasi, Romania, 10-13 April 2013), $462-466$. https://doi.org/10.1016/j.sbspro.2013.08.702

Mazur, M. J., \& Plumley, A. H. (2007). Understanding the Tax Gap. National Tax Journal. Sep2007, 60(3), p569-576. 8p. 1 Diagram, 1 Graph. , Database: Business Source Complete

Miskam, M., Noor, R. Md., Omar, N., \& Aziz, R. Abd. (2013). Determinants of Tax Evasion on Imported Vehicles. In International Conference on Economics and Business Research 2013 (ICEBR 2013). Procedia Economics and Finance, 7, 205-212. https://doi.org/10.1016/S2212-5671(13)00236-0

Morgan-Thomas, M. (2013). Closing The U.S. Tax Gap: Legislative Efforts Counting Cross-Border Anti-Tax Avoidance Practices. Proceedings for the Northeast Region Decision Sciences Institute (NEDSI), 58-61.

Reckon LLP. (2009). Study to quantify and analyse the VAT gap in the EU-25 Member States. Retrieved from http://ec.europa.eu/taxation_customs/resources/documents/taxation/tax_

Rubin, M. (2011). The Practicality of the Top-down approach to Estimating the Direct Tax-Gap Her Majesty's Revenue and Customs, UK, September 2011 Retrieved from https://www.gov.uk/government/publications/the-practicality-of-atop-down-approach-tothe-direct-tax-gap or https://www.irs.gov/pub/irs-soi/11 rescontaxgap.pdf

Perabavathi, S., Zainol, B., \& Syed Soffian Syed, I. (2015). Procedia - Social and Behavioral Sciences vol. 211 p. $299-305$. https://doi.org/10.1016/j.sbspro.2015.11.038

SPKC. (2015). Health Behaviour among Latvian Adult Population. The Centre for Disease Prevention and Control in Latvia.

State Revenue Service. (2016). The legitimate consumption of cigarettes. State Revenue Service in Latvia.

Tax Gap (2005). Multiple Strategies, Better Compliance Data, and Long-Term Goals Are Needed to Improve Taxpayer Compliance: GAO-06-208T. GAO Reports.

TAXUD (2013). Analysis and Feasibility Assessment Regarding EU systems for Tracking and Tracing of Tobacco Products and for Security features.

TAXUD (2013). Communication from the Commission to the Council and the European Parliament. Stepping up the fight against cigarette smuggling and other forms of illicit trade in tobacco products - a comprehensive EU Strategy.

TAXUD (2014). Communication from the Commission to the European Parliament, the Council and the European Economic and Social Committee on the EU Strategy and Action Plan for customs risk management: Tackling risks, strengthening supply chain security and facilitating trade; COM (2014) 527 of 21st August 2014, endorsed by Council in December 2014.

The Tobacco Manifacture's association in the United Kingdom (2017). Tobacco taxation in the UK. Retrieved from http://www.the-tma.org.uk/wp-content/uploads/2017/02/TMA-Taxation_Briefing_final.pdf

The article has been reviewed.

Received in March, 2018; accepted in October, 2018. 